\title{
CONVERTIBLE DEBT AND INVESTMENT INCENTIVES
}

\author{
T. Harikumar \\ University of Alaska \\ P. Kadapakkam \\ University of Michigan \\ Ronald F. Singer \\ University of Houston
}

\begin{abstract}
In this paper we examine the effect of convertible debt on the investment incentives facing stockholders. The effect depends critically on the value of existing assets relative to the firm's investment requirements. With a restrictive dividend covenant, convertible debt mitigates the overinvestment incentive associated with risky debt but exacerbates the underinvestment incentive at higher values of existing assets. A less-restrictive dividend covenant exacerbates overinvestment under straight debt financing but reduces the underinvestment incentive induced by the conversion feature. In this context, a convertible debt contract with a less-restrictive dividend covenant maximizes firm value.
\end{abstract}

\section{Introduction}

The agency relation between bondholders and stockholders induces suboptimal investments. These costs can be broadly classified as an underinvestment problem (Myers (1977)) and an overinvestment or risk-shifting problem (Jensen and Meckling (1976)). A substantial body of literature addresses the mitigation of these problems with different bond indenture provisions. However, the effect of a conversion feature on the firm's investment incentives remains unresolved. For example, Barnea, Haugen, and Senbet (1980) assert that the conversion feature mitigates the underinvestment problem, while Smith and Warner (1979) suggest that it exacerbates the underinvestment problem. Green (1984), abstracting from the underinvestment problem, shows that a conversion feature mitigates the overinvestment incentive.

In this paper we study the effect of convertible debt on both potential underinvestment and overinvestment. We use financial slack to determine the effect of the conversion feature on investment incentives. Whether convertible 
debt induces underinvestment or overinvestment depends critically on the level of financial slack generated by existing assets.

In particular, convertible debt is analogous to straight debt with an embedded call option. The debt component of these securities creates incentives to overinvest or underinvest. The embedded call option can induce the firm's managers to reduce risk (e.g., see Barnea, Haugen, and Senbet (1985)), thereby mitigating the overinvestment incentive and possibly exacerbating the underinvestment incentive. 'However, the call option's effect depends on the value of assets in place (or financial slack). When bondholders convert, they lose their seniority over other claimants. Without financial slack, new securities issued to finance the investment opportunity dilutes the call option value. Thus, as financial slack from existing assets increases and the reliance on external financing decreases, the option's value and its resulting effect increase.

Convertible debt is also analogous to outside equity with a put option. As the value of existing assets increases, this put option loses value and convertible debt behaves like equity. As a result, the conversion feature's effect on the firm's investment incentive is nonmonotonic with the performance of existing assets.

The above relation between the investment incentives of convertible debt and the performance of assets in place depends on a restrictive dividend constraint. While a dividend restriction generally reduces the agency costs of straight debt, a less-restrictive dividend constraint mitigates the underinvestment incentive of convertible debt. This is because a dividend payment can induce voluntary conversion, thereby eliminating the underinvestment problem. For this reason, convertible debt with a less-restrictive dividend constraint dominates straight debt with either dividend constraint.

\section{Assumptions and Notation}

Our analysis adapts the methodology in John (1987) and assumes a threedate (two-period) world. All participants costlessly receive the same information. Today (at time 0), the firm's value consists of the value of existing assets and the value of a single investment opportunity. One period in the future (at time 1), the existing assets generate a stochastic cash flow, $X>0$, and the investment opportunity expires. If accepted, the investment opportunity requires an initial outlay of $I$, and generates cash flow at time 2 of $H$ or $L$, where $H>I>L>0$.

The state, $\Theta$, revealed at time 1 defines $p(\Theta)$, the probability that the growth option will return $H(0<p(\Theta)<1)$. Upon observing $p(\Theta)$ and $X$, the manager acting in the stockholders' interest decides whether to accept or reject

\footnotetext{
'Green (1984) demonstrates that the conversion feature mitigates the overinvestment incentive. However, Green abstracts from Myers's (1977) underinvestment problem and ignores the effect of assets in place, thus ignoring financial slack.
} 


\begin{tabular}{l} 
Time \\
\hline The firm issues either straight \\
or convertible debt maturing \\
at time 2 . \\
The firm has assets in place \\
yielding cash flow at time 1 \\
The firm has an option to \\
to invest at time 1 in a \\
growth opportunity paying \\
off cash flow at time 2 .
\end{tabular}

\section{2}

1

The cash flow from the assets in place is realized.

The net present value of the investment option is realized.

The manager makes the investment decision.

The firm issues new securities to finance the investment if necessary.
3

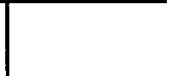

The cash flow from the investment option is realized.

The firm is liquidated.

Figure I. Sequence of Events in the Two-period Model.

the investment opportunity. We suppress the state notation so that $p$ represents the probability of $H$ conditional on state $\Theta$. Figure I summarizes the sequence of events.

The firm finances the investment internally to the extent possible. Any excess cash flow is invested in a zero net present value (NPV) project. This assumption is equivalent to a dividend constraint limiting the dividend to a constant amount regardless of the firm's cash flow. ${ }^{2}$ The firm finances any shortfall with zero coupon subordinate debt with promised payment $F$, payable at time $2 .{ }^{3}$ Finally, at time 2 , the cash flow from the investment is revealed, the firm is liquidated, and all claims are settled.

We also assume:

A1. risk neutrality and a zero time value of money;

A2. frictionless capital markets except for costly recontracting;

A3. the firm's capital structure initially contains equity and risky, zerocoupon straight or convertible debt, each with promised payment $M$ payable at time $2 ;^{4}$ and

A4. strictly enforced me-first rules.

\footnotetext{
${ }^{2}$ The effect of relaxing this constraint is discussed in section IV.

${ }^{3}$ The assumption of issuing subordinated debt is simplifying. The important results would not be affected if the firm issued equity to finance the investment.

${ }^{4}$ The model abstracts from the issue of why a firm should want to issue debt. A tax motivation (e.g., see Heinkel and Zechner (1990)), could provide such a motive. However, tax effects obscure the intuition. A derivation of the model in the presence of taxes is available from the authors on request.
} 
Assumption Al allows the value of a security to be represented by the expected value of the cash flows to its owners. ${ }^{5}$ Assumption A2 focuses the analysis on the agency problem. Once issued, securities cannot be costlessly extinguished by the firm, and participants cannot costlessly negotiate away conflicts. If recontracting were costless, the firm's capital structure decision would not affect stockholders' wealth. Assumption A3 focuses on the conversion feature. The convertible debt can be converted into equity at the option of the bondholders. The debt's dilution factor is defined as $\gamma$; upon conversion, the bondholders receive $\gamma$ proportion of the firm's equity. Assumption A4 requires that a security issued at time 1 be subordinate to the existing debt.

\section{Investment Decision Under Alternative Capital Structures}

We examine the investment decision under three initial financing arrangements. The first is the optimal investment strategy under all-equity financing. This case simply demonstrates the general methodology. An all-equity capital structure eliminates the agency problem since the firm chooses the value maximizing investment strategy. The second and third arrangements incorporate the effects of existing straight debt and convertible debt, respectively, on the firm's investment decision. The investment decision depends on two factors:

1. the information, $p, X$, revealed at time 1 ; and

2. the firm's initial financing.

Define $p_{i}^{*}$ as the minimal probability of $H$, at which the investment will be accepted (given $X$ ) under financing arrangement $i(i=e, s, c)$. Then, $p_{i}^{*}$ characterizes the investment strategy under alternative financing arrangements.

Let $p^{*}$ represent the investment decision to invest if the project's NPV is nonnegative. Then, $p^{*}$ is the solution to:

$$
p H+(1-p) L-I=0
$$

Comparing $p_{i}^{*}$ with $p^{*}$ gives the effect of the initial financing decision on the firm's investment incentive. Investment decisions characterized by $p_{i}^{*}>p^{*}$ represent underinvestment. That is, the firm rejects positive NPV investment opportunities in states where $p_{i}^{*} \geq p>p^{*}$. Alternatively, $p_{i}^{*}<p^{*}$ represents

\footnotetext{
${ }^{5}$ The analysis could be generalized to account for positive time value of money and risk aversion. Then, the probabilities of the growth opportunity returning $H$ or $L$ denoted as $p_{H}$ and $p_{L}$, respectively, would represent state-contingent prices. The sum of $p_{H}$ and $p_{L}$ would equal $1 /(1+r)$, where $r$ is the risk-free rate. While this change requires subsequent expressions to incorporate the state-contingent prices, the central results regarding the role of the conversion feature are unchanged.
} 
overinvestment. In this case, the firm accepts negative NPV investment opportunities in states where $p_{i}^{*} \leq p<p^{*}$ (see John (1987)).

\section{Optimal Investment Strategy for an All-Equity Firm}

First, consider the case where the investment outlay exceeds the cash flow from existing assets. The firm finances the shortfall $(I-X)$ with proceeds from a new debt issue with promised payment $F$. The investment decision can be described by the rationality constraint:

$$
p F+(1-p) \operatorname{MIN}[L, F]=I-X
$$

and the investment criterion:

$$
p(H-F)+(1-p) \operatorname{MAX}[L-F, 0] \geq X
$$

Equation (2) ensures that the market value of the new debt equals the needed funds. Expression (3) ensures that the expected cash flow to the stockholders from accepting the project is at least as large as the equity value if the firm rejects the project.

The solution to the equality in (3), subject to equation (2), characterizes the investment decision for a pure equity-financed firm, as given in equation (4):

$$
p_{e}^{*}=(I-L) /(H-L)
$$

The optimal investment strategy when the firm has sufficient internal funds to invest in the project, $(X \geq l)$, is the solution to (5):

$$
p(H+X-I)+(1-p)[L+X-I]=X
$$

or,

$$
p_{e}^{*}=(I-L) /(H-L)
$$

Notice that the optimal investment strategy is independent of $X$. This strategy is the value-maximizing decision: invest as long as the investment opportunity has a nonnegative NPV (i.e., $p_{e}^{*}=p^{*}$ ).

\section{Effect of the Conversion Feature on Investment Incentives}

The effect of the conversion feature depends on the magnitude of the cash flow from existing assets. We analyze the investment incentive both when the 
firm's cash flow is insufficient to finance the investment and when its cash flow is greater than the investment outlay.

Investment Incentives with External Financing. Proposition 1 describes the effect of the conversion feature when the firm uses external funds to finance the investment.

Proposition 1. Let $X_{*}=I-[(I-L)(H-M) /(H-L)]$ be the value of $X$ that induces a value-maximizing investment strategy for both straight and convertible debt. Let $Z=[M(I-M) / \gamma(H-M)]+M(H-I) /(H-M)$ be the threshold value of $X$ below which the conversion option is valueless at $p_{c^{*}}^{*}$ Then, for $0 \leq X<X_{*}$, the investment incentives are such that $p_{s}^{*}=p_{c}^{*}>p^{*}$, and both straight and convertible debt induce underinvestment. For $X_{*}<X<Z$, the investment incentives are such that $p_{s}^{*}=p_{c}^{*}<p^{*}$, and both straight and convertible debt induce overinvestment. For $Z<X<I$, the investment incentives are such that $p_{s}^{*}<p^{*}, p_{s}^{*}<p_{c}^{*} \gtrless p^{*}$, and straight debt induces overinvestment but convertible debt mitigates the incentive and can cause underinvestment.

Proof 1. For straight debt financing, if the firm rejects the investment opportunity the equity value will be $\operatorname{MAX}[X-M, 0]$. Therefore, the firm accepts the project if and only if the rationality constraint (6) and investment criterion (7) are satisfied. ${ }^{6}$

$$
\begin{gathered}
p F=I-X \\
p(H-M-F) \geq \operatorname{MAX}[X-M, 0]
\end{gathered}
$$

Solving equation (6) subject to the equality in (7) gives the optimal investment strategy $p_{s}^{*}$ as:

$$
\begin{aligned}
p_{s}^{*} & =(I-X) /(H-M) \text { for } 0 \leq X<M \\
& =(I-M) /(H-M) \text { for } M \leq X<I
\end{aligned}
$$

For convertible debt financing, if the firm rejects the project, convertible bondholders receive $\operatorname{MAX}[\gamma X, \operatorname{MIN}(X, M)]$, Thus, the stockholders' claim is $\{X-\operatorname{MAX}[\gamma X, \operatorname{MIN}(X, M)]\}$. The firm accepts the project only if the cash flow to equity holders exceeds this amount.

\footnotetext{
$M>L)$.

'Note that the new bondholders are paid only if the project generates $H$, since the initial debt is risky (i.e.,
} 


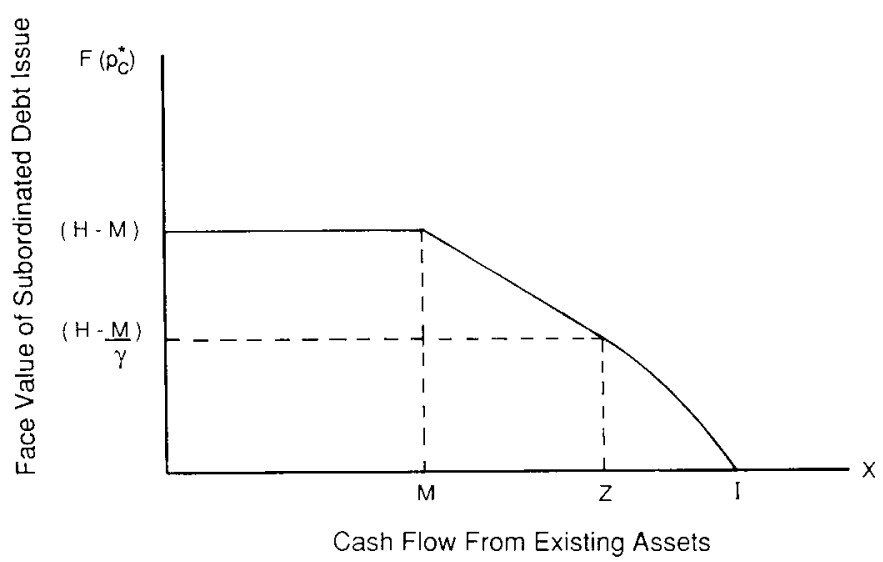

(a)

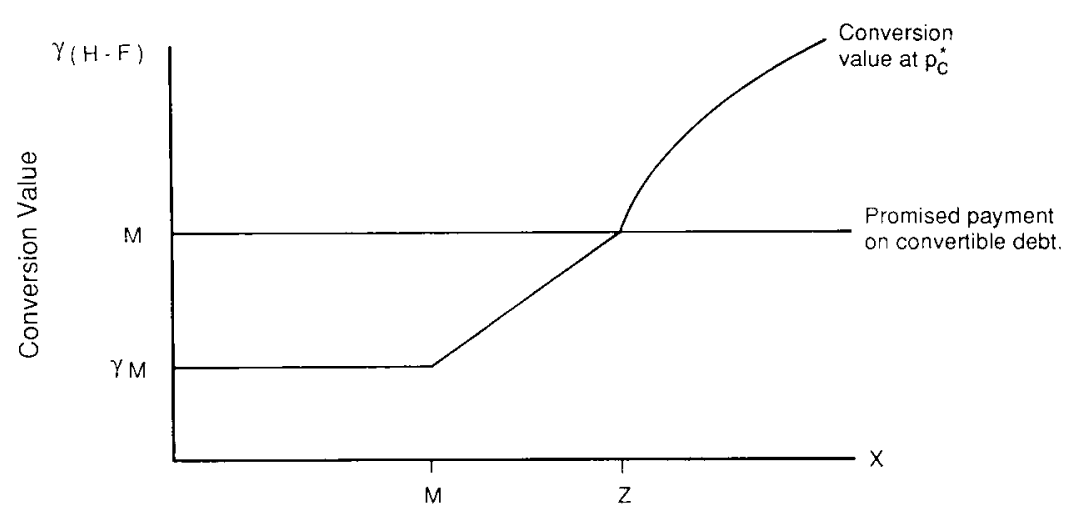

Cash Flow From Existing Assets

(b)

Figure II. The Relation Between the Cash Flow from Existing Assets and the Value of a Conversion Feature. Figure IIa plots the face value of subordinated debt $F$ issued to finance the investment opportunity, requiring an investment $I$ against the cash flows from existing assets $X$. Figure Ilb plots the conversion value at the minimum probability of accepting the project $\left(p_{c}^{*}\right)$. At $Z$ the conversion value equals the promised payment $M$, conditional on the firm's growth opportunities' yielding $H$. The conversion ratio is denoted by $\gamma$.

Notice that the cash flow to outstanding equity at time 2 depends on the bondholders' conversion decision. Their decision depends on the promised payment to the new security holders, since the payment dilutes the conversion value. That is, the optimal conversion strategy is a function of the promised payment to new bondholders $F$. This promised payment must be large enough to finance the shortfall, $I-X$. Thus, the promised payment varies inversely with $X$. Figure II(a) gives the value of the promised payment (computed for $p_{c}^{*}$ ) as a function of $X$. Figure II(b) relates the conversion value to these promised payments. 
Notice that $Z$ is defined as the point at which the conversion value $\gamma(H-F)$ equals the promised payment $M$, and bondholders are indifferent between converting and redeeming. Any value of $X$ less (greater) than $Z$ leads to redemption (conversion) at the minimum investment probability $p_{c}^{*}$. Consequently, the equity value conditional on the firm's taking the project is

$$
p(H-M-F) \text { for } 0 \leq X<Z
$$

in the redemption region, and

$$
p(1-\gamma)(H-F) \text { for } Z \leq X<I
$$

in the conversion region. Stockholders accept the project as long as:

$$
p \operatorname{MIN}[(1-\gamma)(H-F),(H-M-F)] \geq\{X-\operatorname{MAX}[\gamma X, \operatorname{MIN}(X, M)]\}
$$

Thus, the optimal investment strategy is $p_{c}^{*}$, the solution to the equality in (9) subject to (6). This solution is: ${ }^{7}$

$$
\begin{aligned}
p_{c}^{*} & =(I-X) /(H-M) & & \text { for } X<M \\
& =(I-M) /(H-M) & & \text { for } M \leq X<Z \\
& =[I-\gamma(I-X)-M] / H(1-\gamma) & & \text { for } Z \leq X<I
\end{aligned}
$$

Comparing the investment strategy under convertible debt in (10) with that under straight debt in (8) yields the relations in Proposition 1. Q.E.D.

Notice that convertible debt has the same effect as straight debt for cashflow levels below the threshold level $Z$ (see Figure III). Over this region the conversion option has no value so that convertible debt behaves as if it were straight debt. For cash-flow levels above $Z$, the conversion option becomes valuable. Increasing risk raises this option value, transferring wealth to the convertible bondholders. This mitigates the overinvestment incentive. The extent of this mitigation increases with the cash-flow level $X$. In fact, for large values of $\gamma$ and $X$, the conversion option can induce underinvestment. This phenomenon is studied in detail in the next section.

\footnotetext{
${ }^{7}$ This solution assumes that $\gamma X<M$ for $Z<X<I$. If $\gamma X>M$, then $p_{{ }_{c}}^{*}=X /(H+X-I)$. This is an increasing function of $X$, as is the function in the text.
} 


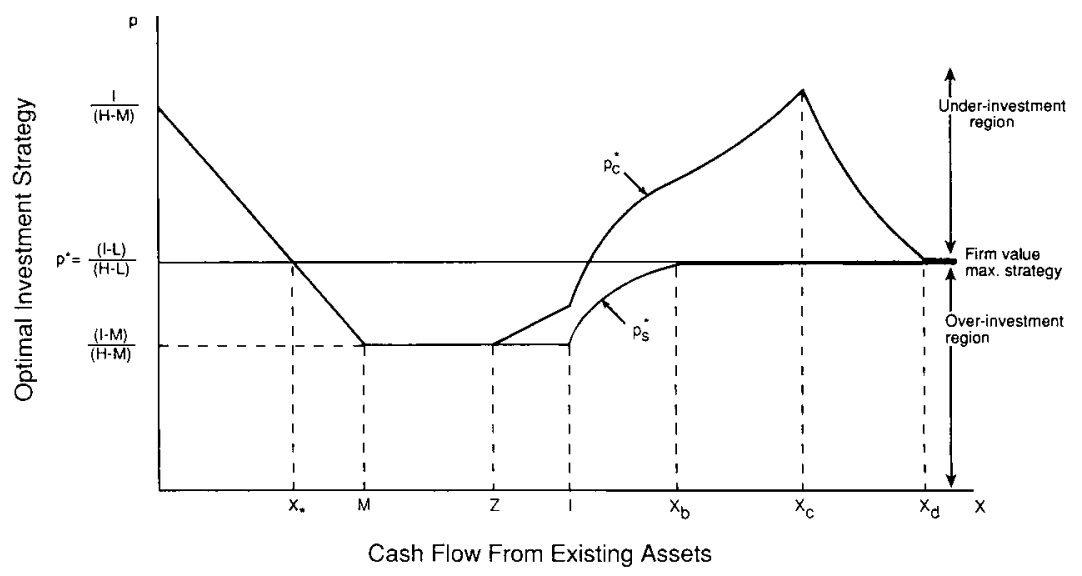

Figure III. Optimal Investment Strategies for Convertible Debt $\left(p_{c}^{*}\right)$ and Straight Debt $\left(p_{s}^{*}\right)$ as a Function of the Cash Flows from Existing Assets $X$. The firm has a growth opportunity requiring an investment $I$ to pay $H$ or $L$ with probability $p$ and $(1-p)$, respectively. The promised payment to the debt holders is $M$. An optimal investment strategy is characterized by the minimum probability of $H$ at which the project is accepted by stockholders. A firm-value-maximizing strategy is given by $p^{*}$.

Investment Incentives with All Internal Financing. Proposition 2 describes the effect of the conversion feature when the growth opportunity is internally financed.

\section{Proposition 2. Define}

$$
\begin{aligned}
X_{b}= & M-L+I \text {, the minimum level of cash flow at which the debt is } \\
& \text { default free; } \\
X_{c}= & M / \gamma, \text { the level of cash flow beyond which the convertible } \\
& \text { bondholders convert at time } 1 \text { if the investment is rejected; and } \\
X_{d}= & M \gamma+(I-L), \text { the level of cash flow beyond which the } \\
& \text { convertible bondholders always convert at time } 2 .
\end{aligned}
$$

Then, for $I \leq X<X_{b}, p_{s}^{*}<p^{*}, p_{s}^{*}<p_{c}^{*} \gtrless p^{*}$, and straight debt induces overinvestment but convertible debt mitigates the incentive and can cause underinvestment. For $X_{b}<X<X_{c}, p_{c}^{*}>p_{s}^{*}=p^{*}$, convertible debt induces underinvestment, and $p_{c}^{*}$ is an increasing convex function of $X$. For $X_{c}<X<X_{d}$ $p_{c}^{*}>p_{s}^{*}=p^{*}$, convertible debt induces underinvestment, and $p_{c}^{*}$ is a decreasing function of $X$. For $X_{d}<X, p_{c}^{*}=p_{s}^{*}=p^{*}$, and both debt contracts induce firmvalue-maximizing strategy.

Proof 2. First, consider the investment decision under straight debt financing. The firm undertakes the project if

$$
p[H+(X-I)-M]+(1-p) \operatorname{MAX}[L+(X-I)-M, 0] \geq \operatorname{MAX}[X-M, 0]
$$


The solution to the equality in (11) gives the optimal investment strategy under straight debt financing as

$$
\begin{aligned}
p_{s}^{*} & =(X-M) /(H-M) & & \text { for } X=I \\
& =(X-M) /(H+X-I-M) & & \text { for } I<X<X_{b} \\
& =(I-L) /(H-L) & & \text { for } X_{b}<X
\end{aligned}
$$

Now, consider the investment decision under convertible debt financing. Absent the investment, the conversion decision can be characterized as $\operatorname{MAX}[\gamma X, \operatorname{MIN}(X, M)]$. The equity value is equal to $X-\operatorname{MAX}[\gamma X, \operatorname{MIN}(X, M)]$. Therefore, the firm invests if

$$
\begin{array}{r}
p(1-\gamma)(H+X-I)+(1-p)[L+X-I-\operatorname{MAX}\{\gamma(L+X-I), \operatorname{MIN}[L+X-I, M]\}] \\
\geq \mathrm{X}-\operatorname{MAX}\{\gamma \mathrm{X}, \operatorname{MIN}[\mathrm{X}, \mathrm{M}]\}
\end{array}
$$

The solution to the equality in (13) gives the optimal investment strategy under convertible debt financing as

$$
\begin{array}{rlrl}
p_{c}^{*} & =(X-M) /(1-\gamma)(H+X-I) & & \text { for } I \leq X<X_{b} \\
& =(I-L) /[(1-\gamma) H-\gamma(X-I)+M-L] & & \text { for } X_{b}<X<X_{c} \\
& =(I-\gamma X-L+M) /[(1-\gamma) H-\gamma(X-I)+M-L] & \text { for } X_{c}<X<X_{d} \\
& =(I-L) /(H-L) & & \text { for } X_{d}<X
\end{array}
$$

Over the range $I<X<X_{c}$, bondholders convert only if the firm accepts the project and the project yields $H$. For values of $X$ between $X_{c}$ and $X_{d}$, bondholders convert if the firm rejects the project or if the firm accepts the project and the project yields $H$. Beyond $X_{d}$ conversion always occurs. Notice that $p_{c}^{*}$ is an increasing concave function of $X$ in (14a), an increasing convex function of $X$ in (14b), and a decreasing function of $X$ in (14c). Comparing equations (14a-d) with (12) gives the relations stated in Proposition 2. Q.E.D.

Without additional external financing (i.e., $X \geq I$ ), the existing straight debt induces overinvestment but not underinvestment. As the assets generate greater cash flow, the straight debt becomes less risky, reducing the overinvestment incentive. Over the range $X \geq X_{b}$, the straight debt is risk free, establishing a value-maximizing investment strategy, $p^{*}$. 
Since convertible debt is equivalent to equity with a put option, it mitigates the overinvestment incentive and can induce underinvestment. If the project is accepted and yields $L$, the expiration value of the put option, $P(X)$, is given by

$$
P(X)=\operatorname{MAX}[0, \operatorname{MIN}(X-I+L, M)-\gamma(X-I+L)]
$$

This can be rewritten as

$$
\begin{aligned}
P(X) & =(1-\gamma)(X-I+L) & & \text { for } X<X_{b} \\
& =M-\gamma(X-I+L) & & \text { for } X_{b}<X<X_{d} \\
& =0 & & \text { for } X>X_{d}
\end{aligned}
$$

For $X<X_{d}$, convertible bondholders exercise their put option. Notice that $P(X)$ is a nonmonotonic function of $X$. When the investment pays $L$, and for very low values of cash flow in (16a), the firm defaults on the promised payment to bondholders. As the cash flow increases within this range, bondholders recover more. Therefore, the value of the put option increases with $X$, reaching a maximum of $M$ at $X=X_{b}$. As $X$ continues to increase over the range in (16b), the put option loses value. At the same time, stockholders risk losing their share of the increasingly valuable asset, $X$. Finally, for $X>X_{d}$ in (16c), the put option becomes worthless. In this range, bondholders always convert. Convertible debt is equivalent to equity, inducing a value-maximizing investment strategy. The interaction of the risk assumed by stockholders and the value accrued to the put option when the firm accepts or rejects the project explains the curvature of the function $p_{c}^{*}$ over the range $I<X<X_{d}$ in Figure III.

In summary, investing tends to increase the put option value, inducing underinvestment. ${ }^{8}$ However, if the cash flow from existing assets is sufficiently high, conversion always occurs and convertible debt behaves like equity.

\section{Dividend Constraints and the Optimal Debt Contract}

Up to this point, the model requires that the firm retain any internally generated funds exceeding the investment outlay. This assumption is equivalent

\footnotetext{
${ }^{8}$ The analysis assumes that the cash flow from existing assets, $X$, is uncorrelated with the profitability of the investment opportunity, $p$. If, however, $X$ and $p$ are positively correlated, underinvestment is mitigated or avoided. Thus, firms with growth opportunities consisting of potential expansion of existing operations are more likely to issue convertible debt.
} 
to assuming fixed dividend payments regardless of the firm's cash flow. We now examine the effect of a less-restrictive (conditional) dividend constraint.

\section{Conditional Dividend Constraint}

The conditional dividend constraint allows the firm to pay out all internally generated funds greater than the investment outlay. Specifically, this dividend constraint requires that an interim dividend, paid at time 1 , be no greater than $\operatorname{MAX}[X-1,0]{ }^{9}$ For the project to be accepted, the dividend plus the exdividend equity value must at least equal the equity value if the project is rejected. For outstanding straight debt, this investment strategy can be characterized by expression (17) for $X>I$.

$$
(X-I)+p(H-M) \geq \operatorname{MAX}[X-M, 0]
$$

Solving (17) for all values of $X>I$ gives the optimal investment strategy as

$$
p_{s}^{*}=[I-M] /[H-M]
$$

Comparing this expression with equation (12) shows that the less-restrictive constraint induces more overinvestment (see also Kalay (1982), John and Kalay (1985), Berkovitch and Kim (1990)). Thus, under straight debt financing a restrictive dividend constraint dominates a conditional dividend constraint.

However, under convertible debt financing the interim dividend can induce voluntary conversion and influence the firm's investment decision. Proposition 3 characterizes the dilution factor $\gamma$ and the dividend constraint that eliminates the perverse investment incentives, given internal financing of the growth opportunity.

PROPOSITION 3. Define the first-best strategy as accept all positive NPV projects and reject all negative NPV projects (i.e., the strategy $p^{*}$ ). Given $H, L, I$, and $p$, and given that $X>I$, a convertible bond contract with promised payment $M, a$ conditional dividend constraint, and a dilution factor, $\gamma=[M(H-L)-L(H-I)] /[H(I-L)]$ induces a first-best investment strategy.

Proof 3. Given in the Appendix.

\footnotetext{
${ }^{9}$ Although the firm has the option of paying less than allowed by the constraint, in the absence of taxes, transaction costs, and stockholder/manager conflicts, risky debt induces the firm to pay the maximum dividend allowed under the constraint.
} 
Notice that $\gamma$ is chosen so that the firm's optimal investment strategy is first best when $X=I$. The optimal investment strategy when $X>I$ depends on the bondholders' decision to convert at time 1. Given that $\gamma$ equals the value given in Proposition 3, the dividend induces conversion for $X \geq M / \gamma$. This leads to a first-best strategy since the convertible bond behaves like equity. On the other hand, if $X<M / \gamma$, the bondholders convert only when $p$ is very high. Nevertheless, the proof shows that the manager's strategy remains first best regardless of the decision to convert. For $X<I$ there is no interim dividend and the analysis is the same as in section III. Thus, a conditional dividend constraint dominates a restrictive dividend constraint under convertible debt financing.

\section{Optimal Debt Contract}

The financing problem involves a choice of a dilution factor and a dividend constraint that maximizes current firm value. From the previous section, the firm will choose between convertible debt with a conditional dividend constraint and straight debt with a restrictive dividend constraint.

Proposition 4. Convertible debt with a promised payment $M$, a dilution factor $\gamma=[M(H-L)-L(H-I)] /[H(I-L)]$, and a conditional dividend constraint dominates straight debt with a restrictive dividend constraint.

Proof 4. Compare the optimal investment strategy under convertible debt as described in Proposition 4 with that under straight debt with a restrictive dividend covenant. According to Proposition 3, for $Z<X<X_{b}, p_{s}^{*}<p_{c}^{*} \leq p^{*}$. In this region of $X$, convertible debt mitigates overinvestment. For all other values of $X$, both debt contracts induce identical investment strategies. Therefore, convertible debt dominates straight debt. Q.E.D.

\section{Conclusions}

In this paper we show that firms with convertible debt reduce the level of investment compared with those with straight debt in the presence of restrictive dividend covenants. Convertible debt then either mitigates the overinvestment problem or exacerbates the underinvestment problem. When the firm's existing assets generate low cash flow, convertible debt behaves like straight debt, inducing the same incentives. However, when existing assets generate moderately high cash flow, convertible debt with a restrictive dividend constraint dilutes the shareholders' stake in the new investment and creates an underinvestment problem. As the cash flow from existing assets increases further, convertible debt behaves like equity and the agency problem disappears.

A less-restrictive dividend constraint mitigates the underinvestment problem under convertible debt financing, but exacerbates the overinvestment 
problem under straight debt financing. A convertible debt contract with a lessrestrictive dividend covenant dominates straight debt financing, thereby maximizing firm value.

Since convertible debt with a liberal dividend constraint is a dominating contract, we should observe more liberal dividend covenants placed on convertible debt as compared with straight debt. Furthermore, convertible debt should be more prevalent in firms with high growth opportunities relative to assets in place. Finally, the ratio $(\gamma / M)$ increases with the book value of the convertible debt $(M)$. Thus, we should find higher dilution ratios in firms that have risky growth opportunities and risky debt outstanding.

\section{Appendix}

Proof 3. We show that $p_{c}^{*}=p^{*}$ for all values of $X>I$.

If the project is taken, the bondholder is indifferent between converting the bond at time 1 and holding the bond for one more period, whenever

$$
\gamma(X-I)+P_{I} \gamma H+\left(1-P_{I}\right) \gamma L=P_{I} \gamma H+\left(1-P_{I}\right) L
$$

where $P_{I}$ denotes the probability of receiving $H$ at which the bondholder is indifferent to the timing of the conversion. If the project is not taken, the bondholder converts at time 1 whenever the conversion value, $\gamma X$, is greater than $M$, i.e, $X>M / \gamma$.

We evaluate the manager's strategy when (i) $X=I$, (ii) $I<X<M / \gamma$, and (iii) $X \geq M / \gamma$. The optimal investment strategy for $X=I$ is given by equation (14a) in the text. Conditional on $X=I, p_{c}^{*}=p^{*}$ if

$$
\gamma=[M(H-L)-L(H-I)] /[H(I-L)]
$$

For $I<X<M / \gamma$, if the project is not undertaken, bondholders do not convert at time 1 and redeem their bonds at time 2 . If the project is undertaken, bondholders may convert at time 1 if $p$ is sufficiently high. We consider involuntary conversion and voluntary conversion.

Involuntary conversion occurs when $p<P_{l}$. Substituting (A2) into (A1) shows that $P_{I}>p^{*}$ for $I<X<M / \gamma$. Thus, the optimal strategy is to invest when,

$$
(X-I)+p(1-\gamma) H \geq \operatorname{MAX}[0, X-M]
$$

The solution to the equality in (A3) gives $p_{c}^{*}=p^{*}$.

Voluntary conversion occurs when $p>P_{I}$. Since from (A1) $P_{I}>p^{*}$, it follows that $p>p^{*}$. If bondholders convert, the optimal strategy is to invest if, 


$$
(1-\gamma)(X-I)+(1-\gamma)[p H+(1-p) L] \geq \operatorname{MAX}[0, X-M]
$$

This yields $p_{c}^{*}<p^{*}$, which is inconsequential because the investment strategy causes acceptance of only profitable projects since the realized $p>p^{*}$.

For $X \geq M / \gamma$, bondholders convert at time 1 if the project is not accepted. We derive the investment strategy under the assumption that bondholders convert even if the project is accepted. We test the consistency of this assumption. The manager's optimal strategy is to invest when,

$$
(1-\gamma)(X-I)+p(1-\gamma) H+(1-p)(1-\gamma) L \geq(1-\gamma) X
$$

This yields $p_{c}^{*}=p^{*}$. Consistency of the bondholder's decision to convert requires that $p_{c}^{*} \geq P_{I}$. From equations (A1) and (A2), we can show that $p^{*} \geq P_{I}$ for $X \geq M / \gamma$ and, therefore, $p_{c}^{*} \geq P_{I}$.

\section{References}

Barnea, A., R. Haugen, and L. Senbet, 1980, A rationale for debt maturity structure and call provisions in the agency theoretic framework, Journal of Finance 35, 1123-34. , R. Haugen, and L. Senbet, 1985, Agency Problems and Financial Contracting (Prentice-Hall, Englewood Cliffs, NJ).

Berkovitch, E. and E. H. Kim, 1990, Financial contracting and leverage induced over- and underinvestment incentives, Journal of Finance 46, 765-94.

Green, R., 1984, Investment incentives, debt and warrants, Journal of Financial Economics 13, 115-36.

Heinkel, R. and J. Zechner, 1990, The role of debt and preferred stock as a solution to adverse investment incentives, Journal of Financial and Quantitative Analysis 25, 1-24.

Jensen, M. C. and W. Meckling, 1976, Theory of the firm: Managerial behavior, agency costs and capital structure, Journal of Financial Economics 3, 305-60.

John, K., 1987, Risk-shifting incentives and signalling through corporate capital structure, Journal of Finance $42,623-42$.

and A. Kalay, 1985, Information content of optimal debt contracts, in E. I. Altman and M. Subrahmanyam, eds.: Recent Advances in Corporate Finance (Irwin, Homewood, IL).

Kalay, A., 1982, Stockholder-bondholder conflict and dividend constraints, Journal of Financial Economics 10 , $211-33$.

Myers, S. C., 1977, Determinants of corporate borrowing, Journal of Financial Economics 5, 147-76.

Smith, C. W. and J. B. Warner, 1979, On financial contracting: An analysis of bond covenants, Journal of Financial Economics 7, 117-62. 